\title{
Gender Analysis of Income Distribution among Rural Households: The Case of Sodo Zuria Woreda, Wolaita Zone, SNNPR
}

\author{
BIRKINESH GEBEYEHU (M.Sc.) \\ Department of Agricultural Economics, College of Agriculture, Wolaita Sodo University,P.O.Box.138
}

\begin{abstract}
Despite wide belief that income distributions were unequal among the female and male headed households in southern parts of Ethiopia in general and Soddo-Zuria Woreda in particular, very few studies have been conducted on gender analysis of income distribution on rural area to empirically demonstrate both at regional and national levels. Therefore, this study intended to compute gender roles in crop production, level of income distribution among male headed and female headed households and identify major determinants of income among male headed and female headed households. This study uses data and information collected from of 154 households, of which 94 male headed and 60 female headed. A multistage sampling technique was used to select the households. The study employs Gini coefficient to estimate income distribution; and multiple linear and Quaintiles regression to identify determinants of income level among female-headed households and male-headed households. The key finding of the study is that gender was Significant at $1 \%$ probability level and had a positive influence on income. The result of this study reveal that income was more evenly distributed among the male headed households than the female-headed counterparts and participation of female headed households in crop production was less than male headed households. The results also show that annual income of male headed households was higher by $25.4 \%$ than the income of female headed households. By using t-statistics annual income of the total sample households was significantly affected by age of household, farm size, access to credit, technology, extension visit and access to off farm income activities. All significant variables are positively influenced on total income of total sampled households except age and access to credit. Only access credit, technology and off farm income significantly influenced the income of male-headed households. Extension visit, technology and off farm income significantly and positively influenced income of the female-headed households. The findings of this study entail that policy makers should develop the extension system that increases number of extension visits to female headed farmers. Efforts should be made to empower and initiate female headed households through various programs that improve their technology uptake and build their confidence to involve in other business activities and intensify their income. It is also suggested that the issue of rural financial service receive greater attention by government and service providing financial institutions.
\end{abstract}

Keywords: Female-headed households, male-headed households, income distribution, Soddo-Zuria

DOI: $10.7176 / \mathrm{EJBM} / 12-31-04$

Publication date: November $30^{\text {th }} 2020$

\section{INTRODUCTION}

\subsection{Background of the study}

Most of developing country rural households depend on agriculture as their main source of income and food. In Ethiopia, over $85 \%$ of the population live in the rural areas and depend on subsistence agriculture and generate income from agriculture (Elizabeth, 2011). About $48 \%$ of the agricultural labor force is driven from female family members (FAO, 2011).

According to the World Development Indicators of 2006, Ethiopia is one of the least developing countries in the world, with a per capita Gross National Income (GNI) of 110.00 USD (CSA, 2009). In the SNNPR; agriculture is also the backbone of the regional economy; contributing for about $73 \%$ of the regional GDP and more than $90 \%$ of the total employment (BOFED, 2005). In addition to the main reproductive and domestic roles they are ought to play, in study area rural women' productive role comes from their involvement in direct crop production, livestock rearing, home management activities and marketing of agricultural products and off-farm activities. Generally, women contribute greatly to food security at household and at national levels. So, improving women producers' income implies a multidimensional contribution to the overall growth of the country.

Rural women play significant contribution to agriculture and food security but they continue to have a poorer command over a range of productive resources, including education, land, information and financial resources (Odame et al. 2002; Welch et al. 2000). A study done by Udry et al. (1995) in Burkina Faso found higher yields on men's plots than on similar women's plots simultaneously planted with the same crop within the same household. The study showed that yield differentials are due to significantly higher labour and fertilizer inputs on plots controlled by men. Unequal productivity among male headed households (MHHs) and female headed households (FHHs) in crops resulted unequal income distribution. A major chunk of women's labour force in 
production system is invested in weeding, harvesting, household animal care, marketing, post- harvest handling etc. (Ranjan and Hedija, 2004). Harrowing and weeding, in particular, are considered as women's activities. Women are also active in livestock production.

The World Bank policy report (World Bank, 2001) entitled 'Engendering Development' concludes that internationally, women-headed households and women cultivated plots produced lower yields and that creates lower incomes from it. Some exceptions have also demonstrated that female-headed households achieve the same or higher yield and income than male-headed households (Jamison and Lau 1982). They produce the biggest workforce in food production, processing and preparation; either as family members or in their own right as women heading households most is by generating income from crop product (Lemlem, 2010).

In Ethiopia, it is repeatedly stated that gender inequality remains as problem that has characterized in poor agricultural production and income generation. Gender inequalities and lack of attention to gender in agricultural development contribute to lower productivity, lost income and higher level of poverty. Women headed households play a crucial role in agriculture and generating income from agriculture activities but there is a wide gender gap in terms of access to assets like land, oxen, credit, inputs and agricultural service (Nina de Roo, 2011). Gender policies are proposed to reduce rural poverty, improve women's' incomes and get children out of work and into school(Giz, 2013). Despite these policy initiatives of economic and social constraints coupled with cultural norms and practices continue to limit women headed household's contribution on agricultural output improvement and income generation activities.

It has been identified that the inequality in gender performance and participation is derived more from inequality in income (Iheke, 2006). These observed inequalities in income are based on physical factors, skill, distributional and input imbalances. It has been shown that women in farming households can be as productive as their male counterparts when given access to appropriate resources (World Bank, 1997 and Quisumbing, 1994).

In agriculture production, gender inequality in labor results in income inequality among rural household in study area. Gender participation is a term that describes the roles and activities of men and women according to traditions and beliefs of a particular culture (Amare, 2012). Female-headed farmers tend to respond more to lowvalue and low-yield subsistence crops in which they tend to specialize, while male-headed households respond more to commercial and fertilizer intensive crops (Abrar, 2004).

In Sodo Zuria, considerable gender differences exist in the agriculture tasks performed by men and women on the farm and household levels. A lots of role-played by women farmer in agriculture, however, very few of them own or control productive resources (Opio, 2003). Such resources are land, credit, technical services, market outlets, and information and education level. They have not received equitable decision making rights with men farmer. Such limited accesses to productive resource and decision making power to women farmers for agricultural production creates income inequality between men and women farmers.

\subsection{Statement of the problem}

Notwithstanding women's contribution to food security, women farmers are commonly underestimated and ignored in income generating activities and trade negotiations processes. They have experienced few concrete benefits and in several cases have even been adversely affected in their living and improvement conditions as result of the implementation of some policies. In fact, there is a general idea among policy makers, politicians, trade officials and negotiators that trade liberalization will reduce poverty equally for men headed farmers and women headed farmers but in reality it not true. The problem of low agricultural productivity and inequality in income distribution exists among male headed and female headed rural HHs. It is also believed that market access will help to increase income and improve the conditions of men headed farmers and women headed farmers equally but women headed households not easily get market access.

Economic constraints, cultural norms, religion and traditional practices are also the major limiting factors for female headed households to gain equal income with male headed HHs in study area. Women are frequently neglected in economic, trade and development policies and planning because of socio historical Patterns in regard to gender-based division of labour. The role of women is generally associated with non-economic and unpaid work, most of which takes place within the so-called reproductive role.

Socio-historical standards and stigmatization of the role of women lead as well to a lack of gender disaggregated data (FAO, 1999), particularly in agricultural activities, which is one important obstacle for policy makers when taking into consideration the gender dimension and performing an in-depth analysis of the impact of developmental policies on women as a group.

According to studies of FAO: "Gender bias and gender blindness persist: farmers are still generally perceived as 'male' by policy-makers and development planners. For this reason, women farmers in rural household find it more difficult than men headed household to gain access to valuable resources such as land, credit and agricultural inputs, technology, market information, education, extension, training and services that would enhance their production capacity and income.

One of the most significance gender specific constraints that women face is access to land. Access to land is 
not just a question of area but also the distance from the residential area and quality of the soil (Arink and Kingma 1991).

Income inequality appears mostly in rural femal headed households due to their higher illiteracy level (Zeresina, 2012). In Sodo zuria woreda, gender responsibilities and income inequality at household head level have not been adequately considered by researcher. But gender inequality has implication for farming responsibilities as it influences the farming activities performed. For example Getachew (1991) pointed out that gender is critical issue in Ethiopian agriculture, but the kind of knowledge and sources of skill are limited for female farmers for their agriculture activities.

In the study area there is still no research conducted on income distribution among rural female headed and male headed households. Therefore this study is aimed at analyzing the socioeconomic characteristics of rural male and female headed households of Soddo Zuria woreda. To determine various activities performed by maleheaded and female headed households in agricultural activities; analyze the level of income distribution between the male and female headed farmers; and to determine the factors of income between male headed and female headed households.

\subsection{Objective}

The general objective of this study was to conduct gender analysis of income distribution among rural households where as the specific objectives are:

- to examine gender roles in crop production among rural households.

- to determine level of income distribution between male headed and female headed households.

- to identify the major determinants of income among male headed and female headed households.

\section{Operational Definitions}

Gender: is used to describe all the socially given attributes, roles, activities, and responsibilities connected to being a male or a female in a given society.

Gender analysis: Such an analysis explores and highlights the relationships of women and men in society, and the inequalities in those relationships, by asking: Who does what? Who has what? Who decides? How? Who gains? Who loses? When we pose these questions, we also ask: Which men? Which women?(Amare,2012)

Gender roles: are roles that are played by both women and men and which are not determined by biological factors but by the socioeconomic and cultural environment or situation (ICA-ILO ,2001).

Socio-economic Factors: this refers to the position of the male headed and female headed farmers in society, which is determined by various social and economic variables such as wealth, income, size of land holding.

Demographic Characteristics: includes the variables related to personal characteristics such as gender, age, marital status, and level of education, household size.

Access to land and other resources: Resources are means and goods including those that are economic like household income, productive like land, equipments, and agricultural inputs

(including labor) and opportunity to leadership and decision-making, information, organization and time. Access to resource implies to the ability to use resources and/or benefits and to make short-term decisions on these resources (Akuna Beatrice, 2004).

\section{DATA AND METHODOLOGY}

\section{Description of the Study Area}

Sodo Zuria Woreda is located in Wolaita Zone of South Nation and Nationality People Regional State $330 \mathrm{~km}$ to the south of Addis Ababa. The Woreda covered an area of 46,006 hectare and have 31 kebeles with total population of 178,890 of which 97,699 are females (CSA, 2007). Soddo Zuria Woreda is bounded in the East and North East by Damot Woyede and Damot Galle Woredas, in the South by Humbo and Offa Woredas, in the West by Kindo Koisha, in the Northwest and Southwest by Boloso Sorie and Offa Woredas respectively. The capital town of the Woreda, Sodo, is located at 06 $51^{\prime} 19^{\prime \prime}$ N, 037047'54" E and 1972 m.a.s.l. The altitude of the woreda ranges from 1400-2950 m.a.s.l. The land area of the Woreda is dominated by rolling hills, plateaus and plains that extend into the low lands of Damot Wayde and Humbo Woredas which are part of the lowlands of rift valley that extend to lake Abaya. Most of the Woreda's land coverage is midland (Woinedega) except the high land areas of mount Damot that experience colder climate. The annual rain fall of the Woreda ranges from $1200 \mathrm{~mm}-1300 \mathrm{~mm}$ and the average maximum and minimum temperature is $28^{\circ \mathrm{c}}$ and $18^{\mathrm{oc}}$ respectively.

The livelihood of the people of Soddo Zuria Woreda is mainly based on agriculture. It is one of the 'Enset' culture parts of the country which is grown as a staple food. Other crops grown in the Woreda include root crops such as sweet potatoes, taro, godere and carrot... etc, cereals such as maize, wheat, barley, teff, sorghum, and pulses. Pulses are mostly grown inter-cropped because of shortage of land. According to Tegegn (1994) the average plot size per farm household in the woreda and the whole Wolaita ranges from 0.5 hectare to 1.75 hectare. But this figure might have been reduced currently due to high population growth that results in land distribution 
among family members.

\section{MAP OF ETHIOPIA}

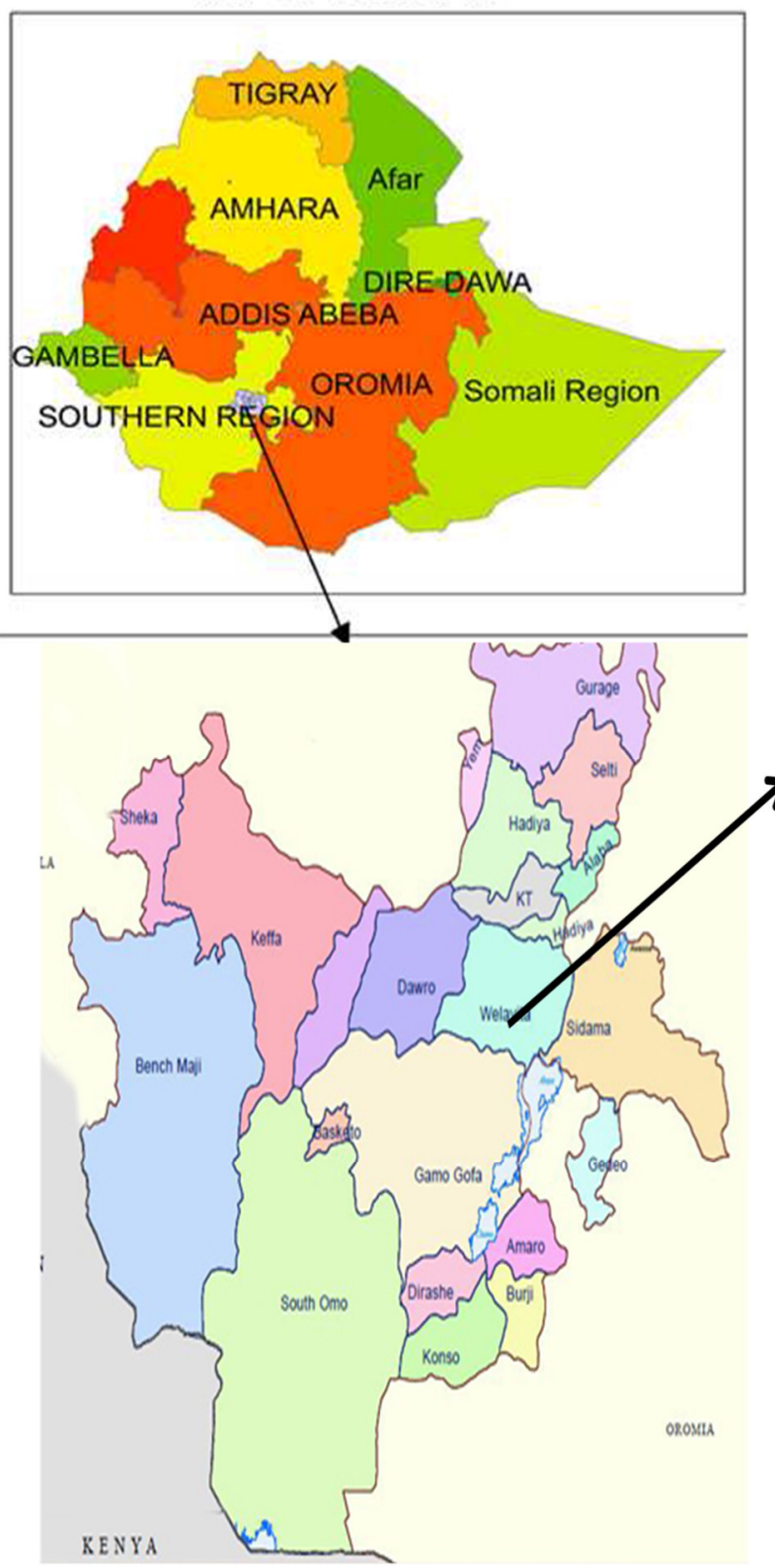

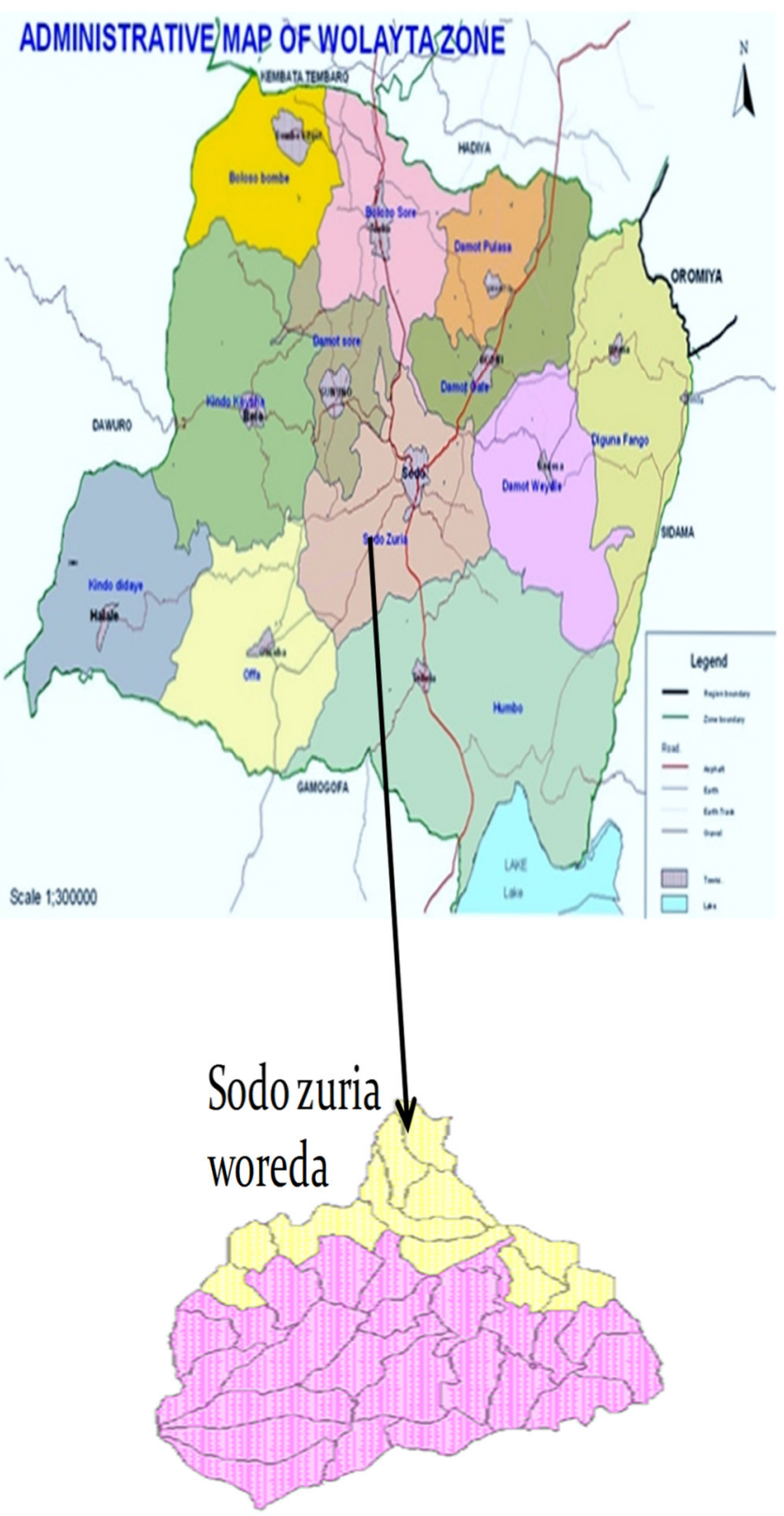

Figure: 2. Map of Study Area

\subsection{Data source and data requirements}

This study used both primary and secondary data. Unit of analysis for the study was crop producing households in the enset based farming system. The secondary data on the target areas demography and socio-economic data was collected from the Woreda Agricultural Development Offices and Women, Children and Youth affair offices and other relevant information

Primary data is cross sectional type and collected mainly from the target crop enset based farming system producers. Demographic characteristics and asset of the households, land area of crop planted, input used for crop production, total production per unit area, total income obtained from sale of the produce, and access to extension, training, fertilizer, improved seed credit, role of gender in agriculture production and marketing are the basic primary data collected to carry out this research.

\subsection{Sample Size and Method of Sampling}

Muilt- stages, clustered, randomized sampling procedure was used for this study. It involved the selection of kebeles, villages and households. Sodo Zuria, which was purposively selected for this research, is among enset producing Woredas in Wolaita Zone. Out of 31 kebeles of Sodo Zuria Woreda, three kebeles (Bosa Kacha, Delbo 
Atwaro and Delbo Wogene) of the Woreda were also randomly selected. Accordingly, four villages were selected from Delbo Atwaro and Delbo Wogene each and three villages were from Bosa Kacha kebele. Through this procedure one hundred fifty four (94 male headed and 60 female headed households were randomly selected for this research.

\section{Methods of data collection}

Data collection was conducted with formal interviews of the randomly selected male headed and female headed households using the pre-tested structured questionnaires. Discussion with the key informants such as Woredas crop production and agricultural marketing experts and Women, Children and Youth affair offices was held to obtain general information on the income distribution among female headed and male headed the role in crop production among male headed and female headed rural households.

\section{Methods of data analysis}

Both descriptive statistics and econometric model were used for analyzing the data from the survey

\section{Descriptive statistics}

Descriptive analysis such as ratios, percentages, frequency distribution, means, ranges and standard deviations were utilized to examine and describe the socio-economic characteristics of male and female headed households engaged agriculture production and the roles of gender in crop production.

\section{Econometric Analysis}

\section{Estimation of income level among male-headed and female-headed households}

We used multiple (OLS) and quaintile regression methods to estimate the effects of independent variables on household's annual income for rural male headed and female headed households. The standard model is based on the human capital earnings function developed Mincer in 1998. OLS equation for estimation of income level as below:

$\ln I N C i=X i \beta+\varepsilon i$

Where:

lnINCi, the dependent variable, is the natural logarithm of the annual income for MHHs and FHHs observation $\mathrm{i}$, and $\mathrm{Xi}$ is victor of independent variables, $\beta$ is coefficient $\left(\beta_{1)}\right.$ the vector of unidentified parameters which will be estimated using OLS method, and ci is a random error term. zi is assumed to satisfy the common properties of zero mean and constant variance (Su and Heshmati, 2013).

OLS is a method of estimating conditional mean functions by minimizing sums of squared residuals.

Similarly, in conditional quantile regression we use an optimization of a piecewise linear objective function of residuals. Equation under conditional quintile regression was;

$\mathrm{Q}_{\mathrm{i}} \ln I N C i(Y)=$ Gender $\beta 1+\operatorname{Edu} \beta 2+\operatorname{EXTEN} \beta 3+$ Technology $\beta 4+$ Age $\beta 5+$ HHsize $\beta 6+$ FM SIZE $\beta 7+$

CREDIT $\beta 8+$ OFFFARMIN $\beta 9+\varepsilon i$

Where $\mathrm{Q} \tau \ln \mathrm{INC}$ is estimate the Mincerian income model at $\tau$-th quantile $(\mathrm{Q} \tau)$ of the distribution of the dependent variable( $\mathrm{Y})$ conditional on the value of $\mathrm{X} . \mathrm{Xi}$ is explanatory variables,

$\beta \tau \quad$ is the estimated parameter for each explanatory variable correspondingly

$\mathrm{X} 1=$ Gender

$\mathrm{X} 2=$ Education $($ EDU

$\mathrm{X} 3$ = Extension agent visit $(\mathrm{EXTEN})$

$\mathrm{X} 4=$ Technology

$\mathrm{X} 5=$ Household head age $(\mathrm{AGE})$

X6 = Household size (HHSIZE)

$\mathrm{X} 7=$ Farm size $(\mathrm{FM}$ SIZE)

$\mathrm{X} 8=$ Credit

$\mathrm{X} 9=$ off farm income activities accesses

Stata software has been employed to run regression model.

\subsubsection{Income inequality measurement among male headed and female headed HHs}

Common measures for the distribution of income among male headed and female headed are the Lorenz curve and the Gini coefficient. The Lorenz curve maps the cumulative income share on the vertical axis against the cumulative distribution of the households on the horizontal axis. (Figure 3). The Gini coefficient can easily be graphically represented by different areas of the Lorenz curve. It is calculated as the area A divided by the sum of areas $A$ and $B$ (see Figure 3). Therefore, the Gini coefficient is defined as $A /(A+B)$, If the area between the line of perfect equality and Lorenz curve is $\mathrm{A}$, and the area under the Lorenz curve is $\mathrm{B}$. If $\mathrm{A}=0$ the Gini coefficient becomes 0 which means perfect equality, whereas if $\mathrm{B}=0$ the Gini coefficient becomes 1 which means complete inequality. It varies between 0 , complete equality and 1 , and complete inequality. Then the Gini coefficient is 
$\mathrm{A} /(\mathrm{A}+\mathrm{B})$. Since $\mathrm{A}+\mathrm{B}=0.5$, the Gini coefficient,

$\mathrm{G}=2 \mathrm{~A}=1-2 \mathrm{~B}$.

$\mathrm{G}=1-2\left(\mathrm{xi}-x_{i-1}\right)\left(\mathrm{yi}+y_{i-1}\right)$.

When there are $\mathrm{N}$ equal intervals on the $\mathrm{X}$-axis this simplifies to

$\mathrm{G}=1-\frac{1}{N}\left(\mathrm{yi}+y_{i-1}\right)$

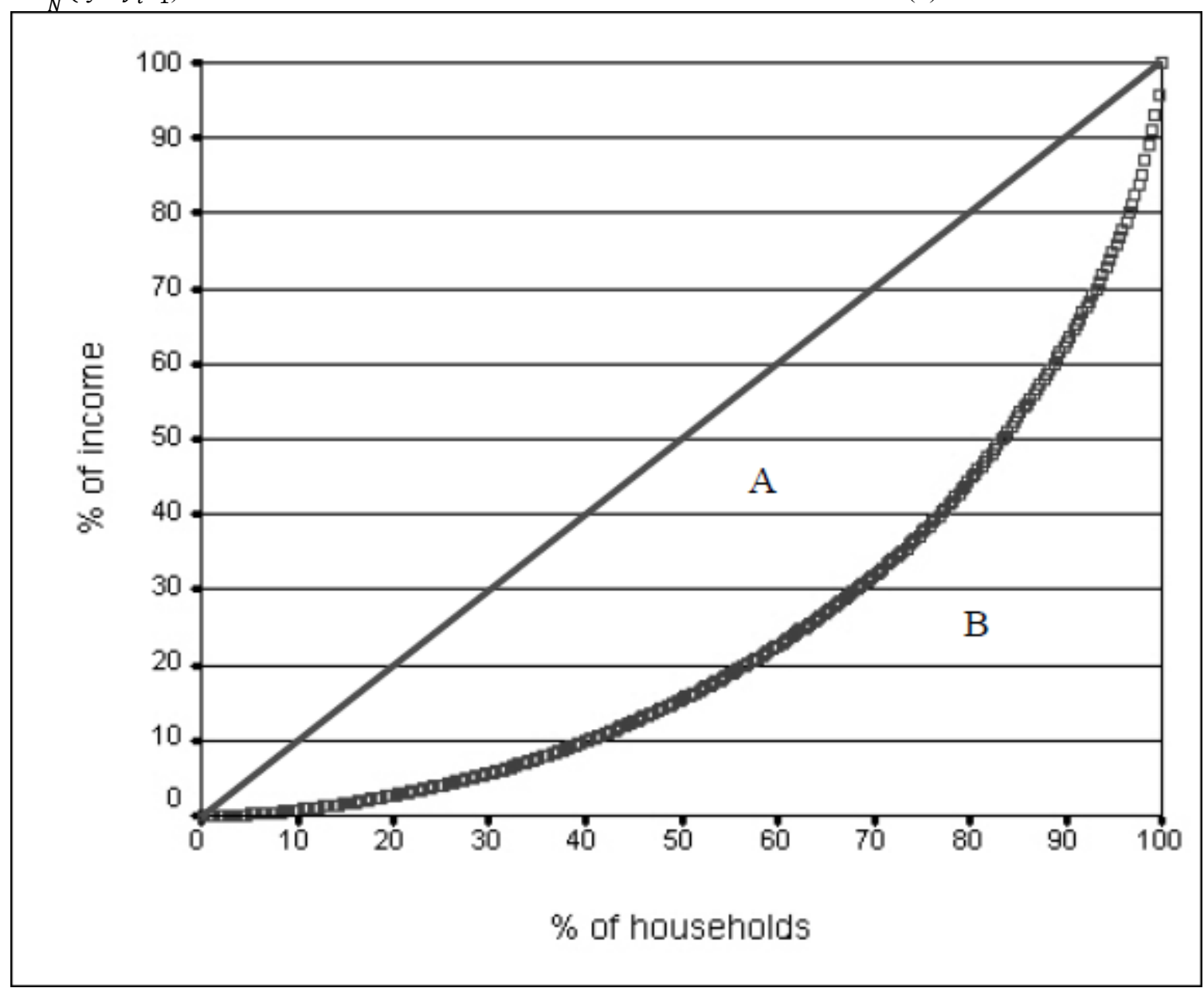

Figure 3: Example of a Lorenz Curve (Shauri, 2013)

Also Gin coefficient can be calculated using Morduch and Sicular (2002), where total male headed and female headed HHs income are ordered so that $\mathrm{y} 1 \leq \mathrm{y} 2 \leq \mathrm{y} 3 \leq \mathrm{y} 4 \leq \mathrm{yn}$.

The Gin coefficient is computed as:

$$
G=\frac{1}{n}\left(n+1-2 \frac{\sum_{i=1}^{n}(n+1-i) y_{i}}{\sum_{i=1}^{n} y_{i}}\right)
$$

Where, $\mathrm{G}=$ gin coefficient $\mathrm{n}=$ number of observation $\mu=$ mean of distribution $\mathrm{yi}=$ income of the ith household 3.5.2.2 Decomposition of inequality by income source

Decomposition can be carried out by income source on the basis that the manner in which the different types or components of income are distributed is likely to explain the overall inequality in the distribution of the total income. Shorrocks (1982) shows that when total income is disaggregated into various components, it is possible to determine the exact contribution (decomposition) of each of the components to the overall inequality.

Income can be obtained from different sources, each of which can have its own contribution to the income of inequality. The aggregate inequality can be expressed as the sum of each income factor contribution. Total income of household i, $y i$, can be expressed as the sum of component incomes, $y i k$, coming from $\mathrm{K}$ different sources $G=\sum_{i=1}^{n} G_{K} S_{K} R_{K}$

$\mathrm{Gk}$ is the Gini coefficient measuring the inequality in the distribution of income component k within the group, $\mathrm{Sk}$ is the share of source $\mathrm{k}$ of income in total group income $\mathrm{Rk}$ is the Gini correlation of income source $\mathrm{k}$ with total income defined by 
$\mathrm{Rk}=\frac{y_{k, F(Y),}}{y_{k, F\left(Y_{K}\right)},}$

Using this decomposition, it is possible to identify how much of overall income inequality is due to a particular income source.

\section{Decomposition of income inequality by factor(sub group)}

Decomposition by factor allows for the impact of the contribution to overall inequality of inequality with and between different factors to be accessed. This will help provide information on which groups are more affected by inequality.

Inequality is involved among a given set of households with given income levels. Inequality may come from different groups (MHHs and FHHs).So, we can see income inequality from different sense, i.e. $I_{W I T}$ (within inequality) inequality among FHHs OR MHHs and $I_{B E T W E N}$ between inequalities between FHHs and MHHs. Thiel index is used to measure the effect of inequality in subgroups to total inequality. The Gini coefficient, GE (0) and GE (1) which are Theil indices are used for the decomposition. Litchfeild (1999) indicates the GE measures with parameters 0 and 1 become two of Theil's measures of inequality. The Theil index respectively, is given as follows:

$$
\begin{array}{r}
G(0)=\frac{1}{n} \sum_{i=1}^{n} \log \frac{y}{y i} \ldots \ldots \ldots \ldots \ldots \ldots \ldots \ldots \ldots \ldots \ldots \\
G(1)=\frac{1}{n} \sum_{i=1}^{n} \frac{y i}{y} \log \frac{y}{y i} \ldots \ldots \ldots \ldots \ldots \ldots \\
I=I_{W I T}+I_{B E T W E N+} k_{R E S I D U A L}
\end{array}
$$

The inequalities in gender, education level, and household size, age of household and off farm income are

\begin{tabular}{|c|c|c|c|}
\hline Independent Variables & Abbreviation & Unit of measurement & Expected sign \\
\hline Gender & Gen & Male $=0$, female $=1$ & +ve \\
\hline Education & EDU & Year & +ve \\
\hline Extension visit & NOEXTN & $($ yes $=1$, no $=0)$ & + ve \\
\hline Household head age & AGE & Years & $+/-\mathrm{e}$ \\
\hline Household size & HHSIZE & Number & $+/-\mathrm{e}$ \\
\hline Farm size & FARMSIZE & Hectar & $+\mathrm{ve}$ \\
\hline Access to credit & CREDIT & $($ yes $=1$, no $=0)$ & $-v e /+v e$ \\
\hline Off farm income activities & OFFARMINC & $($ yes $=1$, no $=0)$ & + ve \\
\hline Technology & Techno & $($ yes $=1$, no $=0)$ & +ve \\
\hline
\end{tabular}
contributed to total income inequality among households.

Table -1 Determinants of income between female headed and male headed households

A positive sign of the estimated parameters of the income model implies that the associated variable have a positive effect on the income.

\section{Tests}

Standard test of mutlicollinearlity and Hetrosedasticity were implemented to clear and structure the data before conducting any formal regression analysis. This was mainly done using STATA 13 software.

\section{Variables and their definitions}

Gender: is a binary variable that is included to estimate the impact of gender on income level of FHHs and MHHs farmers. Household in the study area become female headed if the husband is not alive or if divorced and the other reason is if the husband has migrated. Female headed household would have better opportunity to carry out the farm activity on their plot. In opposite, male headed household heads might be more productive in crop production as they don't engage much in reproductive activities.

Household head Age: is measured in terms of number of years of age of the respondents. Since age is a factor that normally makes the rural women confined more to household chores, it was assumed that age would have a negative relationship with income inequality among male and female HHs.

Education: Education refers to the level of formal and non-formal education and will be measured in terms of ability to read and write and enrolment in primary, secondary schools or above. Educational level as a variable helping HHs how to increase productivity in agricultural production and income. It was hypothesised that education would have a positive relationship with income for male headed and female headed households.

Farm size: Refers to the amount of land the household owned measured in local unit 'Timad' (4 timad is one ha) of cultivated land possessed by the respondents or their families. Land is perhaps the single most important 
resource as it is a base for any economic activity especially in rural area. Farm size influences households' decision to generating income by marketing crop products. It was assumed that larger the farm size, the farmer has, better incomes generation and less income inequality among male and female HHs. Therefore, it was hypothesized that land size has a positive relationship with the dependant variable.

Household size: is the size of the family of the respondent measured in terms of total number of members in the house including aged persons and children. Large household size could also imply that they have enough costless labor for farm activities, but large household size could have a negative effect on household income generation.

Access to credit: Access to credit can relax the financial constraints of women farmers. It indicates whether respondents have access to credit or not. It was expected, in this study, that male farmers have better access to credit than women farmers. Therefore, access to credit has impact on level of income between female and male HHs. Therefore, the variable was assumed to have a positive relationship with the dependant variable.

Extension visit: This represents farmers' frequency of contact with development agents and frequency of participation in extension planning, training, farmers' field day, on-farm trial and demonstration regarding to agricultural production in general. It was assumed that this variable will have a positive relationship with the dependent variables.

Technology: The effect of these variables like use of fertilizer and improved seed is examined by binary response; 1 if yes (have households access to technology) and 0 otherwise. It is supposed to influence income positively thereby increasing productivity and income of households.

Off farm income activities: Farmers off farm income activities is the income source that significantly increases total income and measured by binary response; 1 if yes(households have access to off farm income activities) and 0 otherwise. It was hypothesized to posetive relation to farmer's agricultural income

\section{RESULTS AND DISCUSSIONS}

In this chapter, the results of the study are presented and discussed in detail to address the objectives of the research. The household characteristics include household size, age, education, extension visit, farm size, access to credit, off farm income, gender, and use of technology which are hypothesized to influence the level and distribution of income within and between the MHHs and FHHs.

Multiple linear regression and quantile regression analysis were used to analyze the effects of different household characteristics on the level of household income. Since the Multiple linear regressions establish only the average relationship between the different household characteristics and household income based on the conditional mean function, it does not provide the full picture of the relationship. It will not be helpful to understand the relationship at different points in the conditional distribution of the household income. The quantile regression will, however, allow achieve the objective of establishing the relationship between the different household characteristics at the median or other quantile (e.g., $25^{\text {th }}, 75^{\text {th }}$ percentile) of the household income. Both methods were applied to identify the determinants of the level and distribution of income between FHHs and MHHs in the study area.In addition to the OLS and quantile regression, the Gini coefficient and General Entropy of Thiel's indices of inequality were used for the analysis of income inequality within and between FHHs and MHHs.

\section{Roles of gender in Crop Production}

Gender roles refer to the rights, responsibilities, expectations, and relationships associated with men and women. Gender division of labor among farming communities of study area has been common. Both men and women have been playing a significant role in the crop production. This result was consistent with the findings of Adunga (2012).

Table 16- Roles of gender in crop production

\begin{tabular}{lll} 
& FHHs $(\mathrm{n}=60)$ & MHHs $(\mathrm{n}=94)$ \\
\cline { 2 - 3 } & Percentage & Percentage \\
\hline Planting & 18.12 & 81.87 \\
Weeding & 30.69 & 69.30 \\
Harvesting & 35.90 & 64.13 \\
\hline
\end{tabular}

In Table 16 above, the majority of MHHs households participated in planting (82\%), weeding (69\%) and harvesting $64 \%$ ) of crop production. In contrast, only a minority of the FHHs participated in these activities. The FHHs participated in planting, weeding and harvesting was $18 \%, 31 \%$ and $36 \%$, respectively.

Table 17- Summary Statistics of planting, weeding and harvesting by gender

\begin{tabular}{lccccccccc}
\hline \multicolumn{9}{c}{ FHHs } & \multicolumn{7}{c}{ MHHs } \\
\hline Variable & Mean & Std. Dev. Min Max & \multicolumn{1}{c}{ Mean } & Std. Dev. & Min & Max & \\
planting & 2.77 & 3.032964 & 0 & 12 & 13.97 & 10.04 & 1 & 59 \\
Weeding & 4.85 & 5.249132 & 0 & 30 & 11.95 & 13.83 & 1 & 84 \\
Harvesting & 4.68 & 6.043603 & 1 & 45 & 9.5 & 11.14 & 0 & 89 \\
\hline
\end{tabular}

The result from data shows that, for total sampled respondent's average labor forces that participated in crop 
production were 40.72 mandays per year. Disaggregated by gender, average labor force participation in all crop production among the MHHs and FHHs were 28 mandays and 13 mandays per year, respectively. As a survey result indicates in table 16 above the average force for planting, weeding and harvesting for female farmers were $2.77,4.85$ and 4.68 respectively and the average force for planting, weeding and harvesting for male farmers were 13.97, 11.95 and 9.5 respectively. So, from results we concluded that male farmers engaged more in crop production than female farmers.

\subsection{Econometric Results}

\subsubsection{Interaction of Variables by Gender, Multicollinearity test and Heteroskedasticity test} 4.3.1.1 testing the gender interact action effect

In order to see if the effects of the independent variables on income vary by gender, a standard linear regression was run for both the MHHs and FHHs separately. The coefficients of the independent variables were compared using t-statistics. Results showed that there were no statistically significant differences in the magnitude of the coefficients of the independent variables between the two regression equations for most of the variables except for two variables, access to extension and access to credit. This implies that only credit and extension have varying effects on income depending on gender. The other variables included in the model have the same effect on income, regardless of the gender of the household head.

Table 18- OLS estimation results of interaction of variables by gender

\begin{tabular}{llllll}
\cline { 2 - 5 } Variables & \multicolumn{1}{c}{ MHHs } & \multicolumn{1}{c}{ FHHs } & Total \\
\cline { 2 - 6 } & Coefficient & Sd.error & Coefficient & Sd.error & t-value \\
\hline Household age & 0.0099531 & .0082489 & -.0103386 & .0055149 & 0.00 \\
Education & 0.0375216 & .0243821 & .0264649 & .0324267 & 0.07 \\
Household size & -0.0318876 & .0547344 & .0313201 & .060979 & 0.60 \\
Farm size & 0.2040082 & .1490133 & -.0323414 & .2192376 & 0.01 \\
Credit access & -0.4458128 & .1477733 & -.0323414 & .2192376 & $2.45^{*}$ \\
Technology access & 0.8314035 & .3143274 & .8288021 & .1909959 & 0.00 \\
Extension & 0.0708555 & .1878671 & .5493841 & .1788341 & $3.40^{* *}$ \\
Off farm income & 0.9021924 & .171135 & .5934769 & .2340752 & 0.00 \\
$\quad$-cons & 8.618187 & .5472955 & 7.672628 & .4994853 & 0.00 \\
\hline
\end{tabular}

\subsubsection{Multicollinearity test}

Standard test of multicollinearity was applied to clear and structure the data before conducting any formal regression analysis. The VIF (variance inflation factor) indicates how much the variance of the coefficient estimate is being inflated by multicollinearity. A VIF near to one suggests that there is no multicollinearity, while a VIF near 10 might cause concern and shows a serious multicollinearity effect. This means a commonly given rule of thumb is that VIFs of 10 or higher (or equivalently, tolerances of 0.10 or less) may be reason for concern. Multicollinearity starts becoming a concern when the VIF is over 2.5 and the tolerance is under 0.40 . As it is shown in Table 18 the independent variables had no serious multicollinearity among each other. All the variables had a VIF near to one indicating there was no serious multicollinearity effect on the model.

\subsubsection{Heteroskedasticity test}

In addition to multicollinearlity test, heteroskedasticity test was also conducted. Results of the heteroskedasticity test revealed that the null hypothesis of constant variance (hemoskedasticity) was not rejected at the chosen significance level showing that there was constant variance for all the explanatory variables.

Breusch-Pagan / Cook-Weisberg test for heteroskedasticity

Ho: $\quad$ Constant variance (homoskedasticity)

Variables: fitted values of annual income

$$
\text { chi2 }(1)=1.19 \quad \text { Prob }>\text { chi } 2=0.2447
$$

\subsubsection{Estimation of level of income distribution among male and female headed households}

\subsubsection{OLS Estimation}

OLS regression was run to analyse the relationship between income and independent variables. Since the dependent variable (income) was measured in logarithms, the coefficients indicate the percentage change in the dependent variable as a result of percentage or unit change in the independent variables depending on how the independent variable was measured. A positive coefficient indicates that the level of income of the farmer increases when the independent variable increases. A negative coefficient indicates an inverse relationship that the level of income of the farmer decreases when the independent variable increases.

The results of the OLS estimation in Table 19 revealed that gender, household age, farm size, credit access, technology, extension visit and off farm income were statistically significant determinants of income for the total sampled households. All significant variables had positive effects on total income of total sampled households except age and credit access. When the sample was disaggregated by gender, most of variables which were statistically significant in the total sample turned out to be having statistically insignificant effects on income. This 
is consisting with the finding reported earlier in (Table 18). Only credit access, technology and off farm income had positive and statistically significant effect at $1 \%$ significance level on income among MHHs. Analogously, only eextension visit, technology and off farm income had positive and statistically significant effects on income among FHHs at 1\%, 5\% and $10 \%$ respectively.

Table 19- OLS result of determinant of income for FHHs\& MHHs and total sampled households

\begin{tabular}{lllllll} 
& \multicolumn{3}{l}{ MHHs } & \multicolumn{3}{c}{ FHHs } \\
\cline { 2 - 7 } Variables & Coefficient & t-value & Coefficient & t-value & Coefficient & t-value \\
\hline Household age & 0.0099531 & -1.46 & -0.0103386 & -1.37 & -0.0104357 & $-2.03 * *$ \\
Gender & & & & & 0.933773 & $2.41^{* *}$ \\
Education & 0.0375216 & 1.57 & 0.0264649 & 0.87 & 0.030857 & $1.71^{*}$ \\
Household size & -0.0318876 & -0.64 & 0.0313201 & 0.52 & -0.0008629 & -0.02 \\
Farm size & 0.2040082 & 1.42 & -0.0323414 & 1.64 & 0.223731 & $1.77^{*}$ \\
Credit access & -0.4458128 & $2.73 * * *$ & -0.0323414 & -0.15 & -0.371691 & -0.17 \\
Gender_credit & & & & & -0.4078904 & -1.57 \\
Technology access & 0.8314035 & $2.78^{* * *}$ & 0.8288021 & $3.29 * * *$ & 0.848595 & $4.727^{* * *}$ \\
Extension & 0.0708555 & 0.39 & 0.5493841 & $2.37 * *$ & 0.5409781 & $2.67 * *$ \\
Gende_Extension & & & & & -0.4851512 & $-1.74 *$ \\
Off farm income activities & 0.9021924 & $5.27 * * *$ & 0.5934769 & $2.54 * *$ & 0.785838 & $5.69^{* * *}$ \\
$\quad$-cons & 8.618187 & .547295 & 7.672628 & $11.81^{* * *}$ & 0.4159827 & $18.30^{* * *}$
\end{tabular}

***significant at $1 \%$ level; **significant at 5\% level; *significant at $10 \%$ level

Results of the OLS regression are used to identify the determinants of the variations in household income.

Gender is one of the significant determinants of agricultural production since male headed and female headed households could not have the same capability and endurance in enhancing agricultural production; where the former are stronger (Nyanga et al., 2012). Consistent with expectations, results of the pooled sample showed that gender of the household head had a significant relationship with income. The MHHs was higher by $93 \%$ income than the FHHs.

The coefficients for age were negative and significant at 5\% significance level for the total sample. This implies that as the household head gets older, income goes down. Thus, when households gets older their incomes decreased by $10 \%$. This might be explained by the fact that most of the work is physically demanding and also because older household heads might be too conservative to try new, more efficient techniques to increase household income (GulUnal, 2008). This finding is consistent with the findings of Babatunde and Qaim (2009) in Kwara State of Nigeria where farm income decreases with an increase in age. While the signs of the coefficients of age in the MHHs and FHHs were negative, they were not statistically significant.

Education at all levels plays a crucial part in increasing household welfare, with its effect increasing with educational attainment (Biwei, 2013). Education is also an important factor that sharpens managerial capabilities of farmers. Better educated farmers may have improved access to knowledge and tools that enhance income. As expected the education level of the household head was significantly positively related to income of household for total sampled households. However, it is not statistically significant for the MHHs and FHHs. Education enhances farmers' ability to diversify agriculture, utilize available technologies and increase their income (Unal 2008).

Farmers with access to credit can minimize their financial constraints and buy inputs more readily than those with no access to credit. Thus, access to credit is expected to increase the production of agricultural crops and income among FHHs and MHHs. The coefficient for access to credit was negative and statistically significant for the MHHs. This implies that as the household head gets accesses to credit, income of MHHs decrease. The statistically negative effect might be explained by the fact that it was that most of farmers were used traditional way of credit system and which takes high amount of interest rate in study area. The effects of credit on income vary by gender. The interaction between gender and credit was statistically significant at $10 \%$. Male headed households who have no access to credit $40 \%$ higher than households who have access to credit.

Access to technology includes both use of improved variety and chemical fertilizer usage. The coefficients were positive and significant at 1\% significance level for the total sample, MHHs and FHHs. The annual income of MHHs who have access to technology was $83 \%$ times more than those with no access to technology and FHHs who have access to technology have $84 \%$ times higher than those who have no access. This implies that the variation in the adoption of improved variety and chemical fertilizer could be the main reasons to increase the income for FHHs and MHHs.

Access to extension refers to the sharing of ideas and information which constitutes the large part of the extension agents' job. Having adequate well-presented information will improve the effectiveness of rural income for male headed and female headed households (Deribe, 2007). The coefficient of extension was positive and statistically significant at $1 \%$ for total sample households and statistically significant at 5\% for FHHs. The incomes for FHHs who have access to extension are 50\% higher than those who did not access to extension.

The coefficients for off-farm income activities were positive as expected and significantly affect both MHHs 
and FHHs at $1 \%$ and $5 \%$ significance level, respectively. Off-farm income activities plays significant role in purchasing inputs to increase agricultural productivity and income of rural households from agriculture (Okoye, 2008). The result shows that total annual income of MHHs who have access to off-farm income activities are $90 \%$ greater than those with no access to off-farm income activities. Analogously, the income of the FHHs who have access to off farm income activities was $59 \%$ higher than who were not engaged in off farm income activities.

\subsubsection{Quaintile regression}

Quantile regression analysis is used to analyse the effects of different variables on income on at various levels of the income distribution. (25th, 50th and $75^{\text {th }}$ percentile) for FHHs and MHHs households separately.

The results of the quantile regression presented in Table 20 revealed that variables exhibiting statistically insignificant differences using the OLS regression were found to be significant at other levels. This justifies the appropriateness of the use of quantile regression. For example, education was positively and significantly associated with annual income distribution at the $25^{\text {th }}$ for the MHHs and $75^{\text {th }}$ for the total sample and MHHs, but the OLS estimates of education not statistically significant. This implies that education was more important for the MHHs at the lowest income or poorest level $\left(25^{\text {th }}\right)$ and at the highest level $\left(75^{\text {th }}\right)$ and for total sample it was important at the highest or richest level $\left(75^{\text {th }}\right)$. This is consistent with Biwei(2013) who found that education benefits the richer and poorer households but not the medians.

Table 20- Quintile regression for MHHs, FHHs and total sampled households

\begin{tabular}{|c|c|c|c|c|c|c|}
\hline Ln Income & \multicolumn{2}{|c|}{ MHHs(94) } & \multicolumn{2}{|c|}{ FHHs(60) } & \multicolumn{2}{|c|}{ Total(154) } \\
\hline $\mathrm{q} 25$ & Coefficient & t- value & Coefficient & t-value & Coefficient & t-value \\
\hline Household age & -.0013861 & -0.10 & -.016406 & $-1.81 *$ & -.0147518 & $-2.24 * *$ \\
\hline Gender & & & & & 0.5644803 & 0.75 \\
\hline Education & .0457545 & $1.76^{*}$ & -.01343 & -0.20 & .0324075 & 0.97 \\
\hline Household size & -.0810132 & -0.97 & -.01957 & -0.21 & -.0369994 & -0.50 \\
\hline Farm size & .220585 & 0.73 & .4675306 & 1.31 & .3511218 & $1.76 *$ \\
\hline Credit access & -.2458507 & -0.97 & .0307642 & 0.08 & .1092388 & 0.18 \\
\hline Gender credit & & & & & -.2265688 & -0.66 \\
\hline Technology access & .6585 & 0.74 & .62699 & $2.17 * *$ & .5876177 & $2.11 * *$ \\
\hline Extension & .2902676 & 0.70 & .3606693 & 0.93 & .129664 & 0.61 \\
\hline Gender extension & & & & & .0322437 & 0.07 \\
\hline $\begin{array}{l}\text { Off farm income } \\
\text { q50 }\end{array}$ & .8035961 & $2.43 * * *$ & .434572 & 1.52 & .7780575 & $3.23 * * *$ \\
\hline Household age & -.0060965 & -0.75 & -.01416 & $-1.88^{*}$ & -.0107672 & $-1.95 * *$ \\
\hline Gender & & & & & 1.312589 & $2.92 * * *$ \\
\hline Education & .0270152 & 1.00 & .0020868 & 0.04 & .0323326 & 1.62 \\
\hline Household size & -.0525745 & -0.82 & -.0128017 & -0.19 & -.0531367 & -0.99 \\
\hline Farm size & .2778633 & $1.90^{*}$ & .3671438 & 1.58 & .3802795 & $2.73 * * *$ \\
\hline Credit access & $-.3665-$ & $2.09 * *$ & .1875582 & 0.60 & .6989156 & 1.47 \\
\hline Gender credit & & & & & -.5425875 & -1.98 \\
\hline Technology access & .5525331 & 1.41 & .6813895 & $2.19 * *$ & .7222653 & $3.22 * * *$ \\
\hline Extension & .0705362 & 0.48 &. .4231327 & 1.33 & .8881337 & $1.83 *$ \\
\hline Gender extension & & & & & -.4465127 & -1.60 \\
\hline $\begin{array}{l}\text { Off farm income } \\
\text { Q75 }\end{array}$ & .9667111 & $6.93 * * *$ & .5515661 & $2.42 * *$ & .848369 & $5.29 * * *$ \\
\hline Household age & -.0035689 & -0.33 & -.0055185 & -0.31 & -.00446 & -0.49 \\
\hline Gender & & & & & 1.394542 & $2.15 * *$ \\
\hline Education & .0681244 & $2.17 * *$ & .0022841 & 0.03 & .0506274 & $2.29 * *$ \\
\hline Household size & -.0844591 & -1.14 & .017437 & 0.16 & -.0383754 & -0.83 \\
\hline Farm size & .1693973 & 1.15 & .0924397 & 0.36 & .836034 & 1.02 \\
\hline Credit access & -.5035485 & $-2.36 * *$ & .2250827 & 0.64 & 1.050465 & 1.53 \\
\hline Gender_credit & & & & & -.770323 & $-1.97 * *$ \\
\hline Technology access & .4490 & 1.49 & .808768 & $2.47 * *$ & .8331379 & $3.65 * * *$ \\
\hline Extension & .0163757 & 0.12 & .5457 & 1.28 & .7868691 & 1.30 \\
\hline Gender_extension & & & & & -.4084921 & -1.21 \\
\hline Off farm income & .9307291 & $4.12 * * *$ & .7097826 & $2.11 * *$ & .8101489 & $3.42 * * *$ \\
\hline -cons & 8.618187 & .5472955 & 7.672628 & $11.81 * * *$ & 8.2622 & $21.90 * * *$ \\
\hline
\end{tabular}

\section{Source result of data}

With regard to farm size, the coefficient of farm size increased from $25^{\text {th }}$ quantile to median and positively and significantly associated with income distribution in the total sample. It is also positively and significantly associated with the income of the MHHs at median of the income distribution. But it was not significantly 
associated with income at $25^{\text {th }}$ quantile and $75^{\text {th }}$ income distribution for MHHs. When the farm size of the MHHs increases by one unit, the income of the MHHs increased by 0.27 percent at mean income distribution level. The finding reveals that farm size benefits the MHHs and total sampled at median level income distribution and total sampled at lowest income level.

As for access to technology, the coefficient of technology is positively and significantly related to income in the case of the FHHs. The corresponding coefficient is $62.7 \%$ at 25 th quantile and it increases to $80.8 \%$ at the 75th quantile which also reveals that increasing use of technology increases income for the total sample of households and FHHs significantly.

When it comes to off-farm income, it was positively and significantly associated at $25^{\text {th }}, 50^{\text {th }}$ and $75^{\text {th }}$ quintiles in the MHHs. It was not significantly related to income for FHHs at $25^{\text {th }}$ quantile income distribution but positively and significantly related at the median and $75^{\text {th }}$ quantile. This implies that off-farm income benefits MHHs in the all level and did not benefit poorer but benefited the households at median level and the richest FHHs.

Access to credit did not significantly affect annual income of FHHs and the total sampled households in the OLS regression but results of the quantile regression revealed that it significantly affected the $75^{\text {th }}$ quantile of the income distribution total sampled households at 5\% significance level. This shows that access to credit was not important to poorer households and FHHs and benefits the richest households in study area.

\subsubsection{Income inequality measurement among male headed and female headed $\mathrm{HHs}$}

Table 21, 22 and 23 shows that the Gini coefficient of total income for the total sample is 0.43 . The FHHs and MHHs have Gini coefficient of 0.48 and 0.39 , respectively. This implies that income inequality was higher among the FHHs than among the MHHs. In other words, income is relatively evenly distributed among the MHHs than among the FHHs.

\subsubsection{Lorenz Curve for FHHs and MHHs}

The Gini coefficient can be graphically represented by different areas of the Lorenz curve. Figure 5 below displays the Lorenz curves by gender. When the Lorenz curve is near to the perfect line of equality there is low Gini coefficient and when Lorenz curve is far from line of perfect there is high Gini coefficient. In the figure below MHH's Lorenz curve was near to the perfect line than that of the FHHs, indicating that income was evenly distributed among male headed household than female headed households.

\section{Lorenz curves by gender}

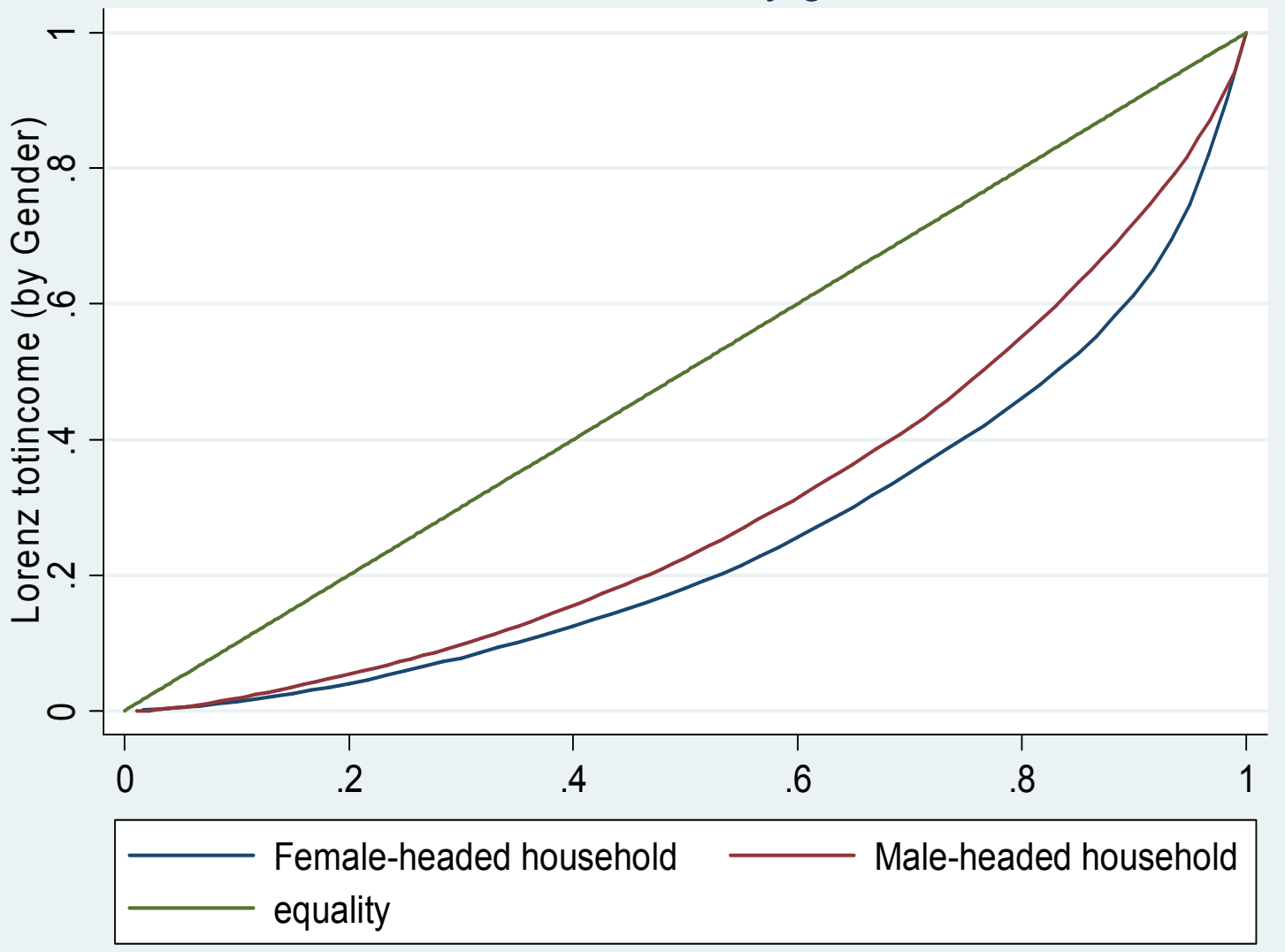

Figure: 5. Lorenz curve for Female headed and male headed households 


\subsubsection{Decomposition of income inequality by income source}

Income was decomposed by its sources to assess the contribution of each income source to overall income inequality. Gini coefficient was decomposed to identify how much of the overall income inequality is due to any particular source of income and this can be used to determine whether inequality in an income source serves to increase or decrease overall income inequality.

Table 21- Gini Decomposition by Income Source for total sample

\begin{tabular}{llllll}
\hline Source & $\begin{array}{l}\text { Share } \\
\text { in total } \\
\text { income } \\
\text { Sk }\end{array}$ & $\begin{array}{l}\text { Gini } \\
\text { Coefficient } \\
\text { for income } \\
\text { source } \\
\text { Gk }\end{array}$ & $\begin{array}{l}\text { Gini Correlation } \\
\text { with total income } \\
\text { rankings } \\
\text { Rk }\end{array}$ & $\begin{array}{l}\text { Share of } \\
\text { the } \\
\text { overall } \\
\text { income } \\
\text { inequality }\end{array}$ & $\begin{array}{l}\text { Impact of } \\
\text { a 1\% } \\
\text { Change } \\
\text { in income } \\
\text { source on } \\
\text { inequality }\end{array}$ \\
\hline $\begin{array}{l}\text { crop income } \\
\begin{array}{l}\text { Livestock income } \\
\text { Total income }\end{array}\end{array}$ & 0.512 & 0.490 & 0.728 & 0.420 & -0.092 \\
\hline
\end{tabular}

Results in Table 21 show that crop income accounts the largest share of the annual income, accounting for $51.2 \%$ followed by non-farm income that contributed $37.7 \%$ of annual income and livestock income that contributed the remaining $11.1 \%$ for total sampled household. A $1 \%$ rise in income from crop production decrease income inequality by $0.092 \%$ for total sampled household. A $1 \%$ rises in income from livestock and off farm income increase income inequality by $0.028 \%$ and $0.064 \%$, respectively.

Table-22 Gini Decomposition by Income Source for FHHs

\begin{tabular}{|c|c|c|c|c|c|}
\hline Source & $\begin{array}{l}\text { Share } \\
\text { in total } \\
\text { income } \\
\text { Sk }\end{array}$ & $\begin{array}{l}\text { Gini } \\
\text { Coefficient } \\
\text { for income } \\
\text { source } \\
\text { Gk }\end{array}$ & $\begin{array}{l}\text { Gini Correlation } \\
\text { with total income } \\
\text { rankings } \\
\text { Rk }\end{array}$ & $\begin{array}{l}\text { Share of } \\
\text { the } \\
\text { overall } \\
\text { income } \\
\text { inequality }\end{array}$ & $\begin{array}{l}\text { Impact of } \\
\text { a } 1 \% \\
\text { Change } \\
\text { in income } \\
\text { source on } \\
\text { inequality }\end{array}$ \\
\hline crop income & 0.509 & 0.510 & 0.841 & 0.448 & -0.060 \\
\hline Livestock income & 0.110 & 0.813 & 0.711 & 0.130 & 0.021 \\
\hline Off farm income & 0.381 & 0.682 & 0.788 & 0.421 & 0.040 \\
\hline Total income & & 0.487 & & & \\
\hline
\end{tabular}

The share of crop income was the largest among both the FHHs (50.9\%) and MHHs (51.3\%) followed by off farm income and livestock that contributed $38.1 \%$ and $11 \%$ for $\mathrm{FHHs}$ and $37.4 \%$ and $11.2 \%$ for $\mathrm{MHHs}$, respectively see Table 22 and 23. This is due to high $\mathrm{Rk}$, which is the correlation of a household's rank in the distribution of each income to their rank in total income. A high Rk coefficient suggests that a household's rank in the distribution of the source income is strongly correlated with that household's rank in the distribution of total income.

Table -23 Gini Decomposition by Income Source for MHHs

\begin{tabular}{|c|c|c|c|c|c|}
\hline Source & $\begin{array}{l}\text { Share } \\
\text { in total } \\
\text { income } \\
\text { Sk }\end{array}$ & $\begin{array}{l}\text { Gini } \\
\text { Coefficient } \\
\text { for income } \\
\text { source } \\
\text { Gk }\end{array}$ & $\begin{array}{l}\text { Gini Correlation } \\
\text { with total income } \\
\text { rankings } \\
\text { Rk }\end{array}$ & $\begin{array}{l}\text { Share of } \\
\text { the } \\
\text { overall } \\
\text { income } \\
\text { inequality }\end{array}$ & $\begin{array}{l}\text { Impact of } \\
\text { a } 1 \% \\
\text { Change } \\
\text { in income } \\
\text { source on } \\
\text { inequality }\end{array}$ \\
\hline crop income & 0.513 & 0.475 & 0.639 & 0.393 & -0.121 \\
\hline Livestock income & 0.112 & 0.830 & 0.638 & 0.149 & 0.037 \\
\hline Off farm income & 0.374 & 0.684 & 0.710 & 0.458 & 0.084 \\
\hline Total income & & 0.397 & & & \\
\hline
\end{tabular}

Results from above Table the decomposition by income source showed that crop income decreases income inequality while non-farm and livestock increase inequality. A $1 \%$ rise in income from crop production decrease income inequality by $0.06 \%$ and $0.121 \%$ for FHHs and MHHs, respectively. In contrast, a $1 \%$ rise in income from off-farm source would increase income inequality by $0.04 \%$ and $0.084 \%$ for FHHs and MHHs, respectively. For FHHs, off farm income significantly affects annual income compared to the case with the MHHs. Livestock income was almost equally affecting total income for MHHs and FHHs. A1\% rise income from livestock production increases income inequality by $0.037 \%$ and $0.027 \%$, respectively for MHHs and FHHs. 


\subsubsection{Decomposition of income inequality by factor (sub group)}

In addition to decomposition by income source, I have implemented income inequality decomposition by factors such as age, education, farm size and others. Since the Gini coefficient is not perfectly decomposable, I have used Thiel's general entropy of indices -GE (0) and GE (1). Results are presented in Table below.

Accordingly Okatch (2003), it is widely known that an income inequality exist between FHHs and MHHs. Most of MHHs active in access to technology and market information that made them to have more income than FHHs. However, most of FHHs are correlated with domestic works which was not paid high.

From Table 25 below it can be observed that male headed households had an income share of $61 \%$ and female headed households had income share was $38 \%$. The inequality indices for female headed household were greater than male headed households. The Gini coefficient for female headed households has greater than male headed households; means income was easily distributed in male headed household than female headed households. All indices also indicate that inequality within the groups is a greater problem than inequality experienced between the groups. This leads that there was female headed households more inequality contribute than male headed households.

Education level is one of the most important social statuses in the community. Thiel's indices of inequality indicate that inequality is more wide spread in the group with no formal education for both the MHHs and FHHs . The Gini coefficient is also higher for the groups with no formal education than for the other groups. Further, inequality within the groups is greater than inequality experienced between the groups. The group with no formal education contributes the highest amount of inequality to the total inequality. This result similar with the studies by Mankiw et al (1992) using Slow's model finds a negative relationship between education and inequality.

Decomposition by age indicates that inequality is maximum in the groups where household heads are older than 64 years old. The Gini coefficient for this group is 0.47 compared to 0.46 for the group of $45-64$ years old and 0.38 for those with below 45 years old. This shows that inequality was the highest for oldest household groups. The age group of above 64 years is the highest inequality contributor to the total inequality

Table 24- Thiel Index Decomposition by demographic factors

\begin{tabular}{|c|c|c|c|c|c|c|}
\hline \multicolumn{7}{|c|}{ By gender } \\
\hline & $\begin{array}{l}\text { Population } \\
\text { share }\end{array}$ & Mean & $\begin{array}{l}\text { Income } \\
\text { share }\end{array}$ & $\mathrm{GE}(0)$ & GE(1) & Gini \\
\hline FHHs & 0.389 & 9292 & 0.386 & 0.43 & 0.43 & 0.48 \\
\hline MHHs & 0.610 & 9400 & 0.613 & 0.30 & 0.27 & 0.39 \\
\hline Within groups & & & & 0.35 & 0.33 & \\
\hline Between groups & & & & 0.0000 & 0.0000 & \\
\hline
\end{tabular}

\begin{tabular}{|c|c|c|c|c|c|c|}
\hline \multicolumn{7}{|c|}{ By education } \\
\hline Illiterate & 0.47 & 8596 & 0.435 & 0.436 & 0.38 & 0.47 \\
\hline Primary & 0.40 & 9433 & 0.406 & 0.256 & 0.25 & 0.38 \\
\hline Secondary and above & 0.12 & 12043 & 0.159 & 0.308 & 0.34 & 0.43 \\
\hline Within group & & & & 0.35 & 0.32 & \\
\hline Between group & & & & 0.005 & 0.006 & \\
\hline \multicolumn{7}{|c|}{ BY age } \\
\hline$<45$ & 0.48 & 9297 & 0.48 & 0.25 & 0.26 & 0.38 \\
\hline $45-64$ & 0.39 & 10051 & 0.42 & 0.44 & 0.39 & 0.46 \\
\hline$>64$ & 0.116 & 7264 & 0.090 & 0.447 & 0.39 & 0.47 \\
\hline Within group & & & & 0.35 & 0.32 & \\
\hline Between group & & & & 0.0045 & 0.004 & \\
\hline
\end{tabular}

Inequality decomposition by household size in Table 25 below, households of size greater than 5 members have higher inequality than otherwise. The Gini coefficient for households with a household size greater than five was 0.44 and for those with a household size of less than five was 0.41 . Therefore, household who have house member greater than 5 contributes high inequality for total inequality. In addition, inequality experienced within the groups is greater than that experienced between. 
Table -25 Thiel Index Decomposition by household size

\begin{tabular}{lllllll}
\hline \multicolumn{7}{c}{ Thiel Index Decomposition } \\
& $\begin{array}{l}\text { Population } \\
\text { share }\end{array}$ & Mean & $\begin{array}{l}\text { Income } \\
\text { share }\end{array}$ & GE $(0)$ & GE $(1)$ & Gini \\
\hline$<5$ (average) & 0.312 & 7222 & 0.24 & 0.34 & 0.27 & 0.41 \\
$>5$ & 0.68831 & 10325 & 0.76 & 0.3368 & 0.33 & 0.44 \\
Within group & & & & 0.340 & 0.319 & \\
Between group & & & & 0.013 & 0.012 & \\
\hline
\end{tabular}

In Table 26 below Thiel index decomposition by farm size in hectare of the household indicates that inequality is higher for households with farm size greater than 0.5 hectare. The Gini coefficient was also high for the households having greater than 0.5 hectares. This shows farm size greater than 0.5 hectares highest inequality contributor to total inequality. There was higher inequality within groups than between groups.

Table -26 Thiel Index Decomposition by farm size in hectare

\begin{tabular}{lllllll}
\hline \multicolumn{7}{c}{ Thiel Index Decomposition } \\
& $\begin{array}{l}\text { Population } \\
\text { share }\end{array}$ & Mean & $\begin{array}{l}\text { Income } \\
\text { share }\end{array}$ & GE $(0)$ & GE $(1)$ & Gini \\
\hline$<0.5$ & 0.68 & 8449 & 0.61 & 0.29 & 0.28 & 0.40 \\
$>0.5$ & 0.39 & 11306 & 0.38 & 0.44 & 0.37 & 0.46 \\
Within group & & & & 0.34 & 0.32 & \\
Between group & & & 0.0095 & 0.0090 & \\
\hline
\end{tabular}

With regard to access to technology in Table below 26, the Gini coefficient is 0.42 for households who have access to technology and 0.35 for those with no access to technology. This shows that households who access to technology is more contribute inequality for total inequality.

Table -26 Thiel Index Decomposition by technology

\begin{tabular}{lllllll}
\hline \multicolumn{7}{c}{ Thiel Index Decomposition } \\
& $\begin{array}{l}\text { Population } \\
\text { share }\end{array}$ & Mean & $\begin{array}{l}\text { Income } \\
\text { share }\end{array}$ & GE $(0)$ & GE $(1)$ & Gini \\
\hline No & 0.123 & 4316 & 0.059 & 0.329 & 0.220 & 0.35 \\
Yes & 0.87013 & 10110 & 0.94 & 0.32 & 0.31 & 0.42 \\
Within group & & & & 0.32 & 0.30 & \\
Between group & & & & 0.033 & 0.026 & \\
\hline
\end{tabular}

Access to agricultural extension services has direct influence on the production and incomes of the farmers. The higher access to the extension service, the more likely that farmers adopt new technology and innovation that increase income of the households. Decomposing total inequality by extension visit in Table 27 below shows that there was high Thiel index of inequality among households have no access to extension visit than those who have access to extension. This shows that households who have no access to extension contribute high inequality.

Decomposition by off farm income access indicates that inequality is higher in groups of households who have access to off farm income than those who have no access to off farm income. The index shows that there was high inequality with in groups than between groups. This implies inequality was high among the households have access to off farm income than those have no access to off farm income and off farm income was highest inequality contributor in study area.

Table -27 Thiel Index Decomposition by credit, extension visit and off farm access

\begin{tabular}{|c|c|c|c|c|c|c|}
\hline \multicolumn{7}{|c|}{ By credit } \\
\hline & Population share & Mean & Income share & $\mathrm{GE}(0)$ & $\mathrm{GE}(1)$ & Gini \\
\hline No & 0.66883 & 10022.54 & 0.716 & 0.382 & 0.377 & 0.465 \\
\hline Yes & 0.33117 & 8016.05 & 0.283 & 0.280 & 0.198 & 0.338 \\
\hline Within group & & & & 0.348 & 0.326 & \\
\hline Between group & & & & 0.0053 & 0.0052 & \\
\hline \multicolumn{7}{|c|}{ By off farm income access } \\
\hline No & 0.266 & 5205 & 0.148 & 0.312 & 0.249 & 0.38 \\
\hline Yes & 0.733 & 10865 & 0.85 & 0.305 & 0.298 & 0.41 \\
\hline Within group & & & & 0.307 & 0.29 & \\
\hline Between group & & & & 0.046 & 0.040 & \\
\hline \multicolumn{7}{|c|}{ By extension visit } \\
\hline No & 0.28 & 7314 & 0.22 & 0.45 & 0.43 & 0.47 \\
\hline Yes & 0.71 & 10176 & 0.77 & 0.29 & 0.29 & 0.41 \\
\hline Within group & & & & 0.34 & 0.32 & \\
\hline Between group & & & & 0.01058 & 0.01002 & \\
\hline
\end{tabular}




\section{CONCLUSIONS AND RECOMMENDATIONS}

This study analysed the gender differential in the level and distribution of income of rural households in Sodo Zuria woreda of the SNNPR. It also identified the major determinants of the variation in both the level and distribution of income. Both linear and quantile regressions were applied to the study data that came from 154 households, of whom $94 \mathrm{MHHs}$ and $60 \mathrm{FHHs}$ who were selected using a multistage sampling technique. Quantile regression was used to capture the non-uniform effects of independent variables at different quantile of the income distribution. The level of income inequality was measured using Gini coefficient. Theil's General Entropy indices of inequality were also applied in the case of the decomposition of the total inequality by factor.

The results showed that age of household head, gender, education, farm size, access to technology, access to extension and access to off-farm income activities are positively and significantly related to household annual income. When the data were disaggregated by gender, the major determinants of the income of the FHHSs were access to technology, extension and access to off-farm income. Similarly, the major determinants of the income of the MHHs were access to credit, technology and access to off-farm income activities. Access to credit is significant and negatively related to income for MHHs, this shows that households who have access to credit have lower income than those who have no access to credit. Access to technology and access to off-farm income activities were found to significantly affect income for both types of households. MHHs that have more access to technology and off-farm income activities compared with Female headed households.

Results of the quantile regression show that education was positively and significantly associated with income for MHHs at the $25^{\text {th }}$ income distribution and for the total sample and MHHs at $75^{\text {th }}$ income distribution. This suggests that education was more important for the MHHs at the poorest level and at the richest level, but it was important for the total sample only at the richest level. Gender has greater effects on the household income at the median level and the richest level income distribution. Farm size has higher effect on income for MHHs at $25^{\text {th }}$ income distribution and for total sampled households at the median level income distribution. Access to credit has an effect on income for the poorest male headed households and median level male headed household and no effect on FHH's income at all level of income distribution. Access to off-farm income activities has greater effect on income in all range of the income distribution level for the FHHs, MHHs and total sample but it has no effect on income for the FHHs at the $25^{\text {th }}$ level of income range.

An estimate of the Gini coefficient indicates that income inequality is greater for the FHHs than the MHHs. This implies that income is evenly distributed among MHHs than FHHs. In other words, income was skewed within the group of the MHHs than the FHHs but there was even less inequality between the MHHs and FHHs in the study area.

This study applied decomposition analysis using Thiel general entropies to examine the impact of different sources of income and factors to explain the variation in income inequality. The sources of income for MHHs and FHHs were crop income, non-farm income and livestock income. As the community in the study area is predominantly an agricultural community, crop income plays a dominant role as an income source followed by non-farm income and livestock. With respect to inequality, non-farm income and livestock income represent an inequality increasing source of income while crop income represents an inequality decreasing source. Results also indicate that inequality within the groups was greater than inequality between the groups.

\subsection{RECOMMENDATIONS}

In the analysis of the role of gender in crop production, the major finding was that there was large inequality in crop roles among MHHs and FHHs. This suggests that the Woreda women, children and youth office together with woreda Agriculture offices should mobilize and initiate FHHs to participate more in crop production. This could be done, on the one hand, by putting in place a system of incentives in the form of inputs and improved agricultural production and processing technologies. On the other hand, men should also be encouraged to share in domestic tasks by putting in place initiatives and incentives that entice men to work more in the house. Further, effective gender sensitization programmes may be required. This could be done through non-formal educational activities, agricultural extension, meetings and mainstreaming gender issues in school curricula at all levels. In addition, informal educational activities organized for rural farmers should take note of the heavy domestic workload of females. These activities should also be scheduled at appropriate times to enable many FHHs to participate in crop production and marketing. Improving participation of women farmers in various areas of extension programmes is the best option for empowering farm women for better production that increase income. Therefore, it is recommended that the Woreda agriculture office should be organize and conduct training programmes based on women's need, in a manner that women are encouraged to attend, taking into consideration timing, duration, location and language; in any training organized for farmers.

- The result of this study data indicated that access to credit significantly influences the income of MHHs. The study also found that the rate of interest charged by informal credit providers is very high. FHHs reported to have paid even more than their counterparts. As improved access to credit addresses the financial liquidity of farmers, formal agricultural credit institutions can play an important role in 
enhancing the ability of farmers to procure and use the required agricultural inputs in crop production which in turn enhances productivity and income. Given that formal financial service in the rural area is low, it is suggested that the issue of rural financial service receive greater attention by government and service providing financial institutions .Finally, the results obtained in this study come out of the cross sectional data which does not consider time varying attributes of the variables. Therefore, it will be interesting to look at income distribution among MHHs and FHHs by using panel data collected over a certain period of time and evaluates income distribution among FHHs and MHHs over time.

\section{REFERENCE}

Abera .G, Gudeta .H, Belissa .M, Shale .G, Degefe. A, Akassa B. 2006. Gender Based Roles and Resource Use Right in Potato Production and Marketing System: The Case of Some Districts in Oromia, Ethiopia. Research Report,Addis Ababa: OARI and OSSREA.

Abrar.2004. Smallholder Supply Response and Gender in Ethiopia: A Profit Function Analysis.

Adugna Eneyew and Wagayehu Bekele. 2012. Analysis of Wealth and Livelihood Capitals in Southern Ethiopia: A Lesson for policy makers. Department of Agricultural Economics and Extension, Jimma University, Ethiopia.

Adugna Eneyew. 2008. Livelihood strategies and food security in Wolaita, Southern Ethiopia: The case ofBoloso Sore District. M.Sc.Thesis, October, 2008.Haramaya University.

Akuna Beatrice.2004. Access to and control over land from a gender perspective. A study

Alawode Yetunde. O. 2011. Economic Analysis of Sweet Potato Production in Odo Otin Local Government Area of Osun State, Nigeria

Almaz.W.2007. Women's access to and control over land in the current land administration system in two rural kebeles in Ada'a woreda of Oromia Region. MSc. thesis, School of graduate studies, Addis Ababa University.

Amare Tegbaru (IITA).2012. Training Manual for Gender Mainstreaming and Analysis. Building Capacity for Agriculture Research for Development (R4D) andInnovation. IITA Research Guide

Andrew R.and Fiona F. 2007. Gender Pastoralism Volume II: Livelihoods \& Income Development in Ethiopia.

Anetneh .2012. Women contribution to household livelihood and food security: the case of pastoral community of Awash Fentale woreda, Afar region, Ethiopia. MSc. Thesis, College of Agriculture, Hawassa University.

Anneli Kaasa, 2003. Factors influencing income inequality in transition economies, University of Tartu Faculty of Economics and Business Administration.

Arink, M. and Kingma, K. 1991. The Shamba is like a child. Women and Agriculture in Tanzania: Women and Autonomous Center: Leiden University,

Awotide Bola Amoke, Awoyemi Taiwo Timothy, Oluwatayo Isaac Busayo, 2012. Gender Analysis of Income Inequality and poverty among Rural Households in Nigeria. Michael Okpara University of Agriculture, Umudike, Abia State, Nigeria.

Ayal Kimhi. 2008. Male Income, Female Income, and Household Income Inequality in Israel: A Decomposition Analysis. Department of Agricultural Economics and Management. The Hebrew University of Jerusalem.

Ayal Kimhi. 2009. Rural non-farm employment and income inequality in southern Ethiopia: the gender dimension. The Hebrew University, Israel.

Babatunde, R.O.; Olagunju, F.I.; Fakayode, S.B. and Adejobi, A.O. 2009. Determinants of participation in off farm employment among small-holder farming households in Kwara State, Nigeria.

Bekelu .T and Abdi-Khalil. E. Determinants and Patterns of Income Diversification among Smallholder Farmers in Akaki District, Ethiopia. MSc. Thesis, Haramaya University, pp. 68-78.

Biwei Su \&Almas Heshmati.2013. Analysis of the Determinants of Income and Income Gap between Urban and Rural China, IZA,Discussion Paper No. 7162.

BoFED. 2005. Socio-Economic Profile of Wolayta Zone. Wolayta Zone Beauro of Finance and Economic Development.

Bourke, R. M. and V. Vlassek.2004. Estimates of Food Crop Production in Papua ew Guinea, Land Management Group, ANU: Canberra.

British Council .2012. Gender in Nigeria Report: Improving the Lives of Girls and Women in Nigeria, 2nd Edition. Central Statistics Agency (CSA). 2007. Ethiopia Census 2007. Retrieved November 15, 2012

Central Statistics Agency (CSA). Tsegaye, A., and Stuik, P. C. 2002. Analysis of enset (Ensete Ventricosum) indigenous production methods and farm-based biodiversity in major enset-growing regions in Southern Ethiopia.Experimental Agriculture, 38(3): 291-315.

Cheryl Doss (2013), Gender analysis in Agriculture. Environment and Production Technology Division. Yale University.

Clare Bishop-Sambrook,2007. Toolkit for Gender Analysis of Crop and Livestock Production, Technologies and Service Provision.

Cristina, 2013. Reducing the gender gap in agricultural extension and advisory services ; How to Find the Best Fit 
for Men and Women Farmers.

CSA.2009. the Federal Democratic Republic of Ethiopia Central Statistical Agency Agricultural Sample Survey 2009/2010 (2002 E.C.) (September - December, 2009) volume IV report on land utilization (private peasant holdings, Meher season), Addis Ababa Statistical Bulletin 468 government printer.

D. Mihaela , A. Dorel and M. Liviu,2013. Analysis of gender discrimination using the Gini index multiple decomposition method: The Bucharest Academy of Economic Studies, Romania.

Danziger, S.1980. “Do Working Wives Increase Family Income Inequality?” Journal of Human Resources, XV(3).

Dejene A. 2003. Integrated Natural Resources Management to Enhance Food Security: the Case for CommunityBased Approaches in Ethiopia. Working Paper No.16. Rome: Food and Agriculture Organization of the United Nations.

Dejene S, .2002. Gender roles in agricultural production among the Sidama of South Western Ethiopia, Addis Ababa.

Deribe, K, 2007. Agricultural information networks of farm women and role of agricultural extension: the case of dale woreda, southern nations, nationalities \& peoples' Region.

Diane Rosenfeld, LLM.2007. Women’s Rights Guide, Bernard Koteen Office of Public Interest Advising Harvard Law School.

Dollar, David and Gatti, Roberta .1999. Gender Inequality, Income, and Growth: Are Good Times Good for Women? Policy Research Report on Gender and Development, Working Paper Series, No. 1, The World Bank.

Elizabeth .A, 2011. Gender, IFIs and Food Insecurity Case Study: Ethiopia.

Ellis F. 2000. The Determinants of Rural Livelihood Diversification in Developing Countries. J. Agric. Econ. 51(2):289-302

FAO .2001. The State of Food Insecurity in the World. Food and Agricultural Organisation. Rome, Italy.

FAO .2003. Focus: 'Women and Food Security'. FAO, Rome..

FAO.1999. Gender Issues in Land Tenure. Paper presented at the High Level Consultation on Rural Women and Information. Food and Agriculture Organization of the United Nations - FAO: 4-6 October Rome.

FAO.2005. Training Manual: Building on gender, agro-biodiversity and local knowledge, Rome, Italy.

Farooq, M.2010. Education and income inequality in Pakistan. The Dialogue, July - September, 2010, Volume V, Number 3, p 228-240.

Fernando P. 1998. Gender and Rural Transport. Gender,Technology and Development, 2: 63-80.

Flintan Fiona, Solomon Demlie, Mohammed Awol, Zahra Humed, Yemane Belete, \& Honey 59

Food and Agriculture Organization (FAO). 2011. The state of food and agriculture 2010-2011: Women in agriculture - closing the gender gap for development. Rome: FAO.

Food and Agriculture Organization (FAO). 2011. The state of food and agriculture 2010-2011: Women in agriculture - closing the gender gap fordevelopment. Rome: FAO.

G. S. Ogato, E. K. Boon and J. Subramani .2009. Gender Roles in Crop Production and Management Practices:A Case Study of Three Rural Communities in Ambo District, Ethiopia.

Galor O, Tsiddon D.2006. "Income Distribution and Growth: The Kuznets Hypothesis Revisited". Economia. Supplement, 63(250): 103-117.

Galor, O. 2000. 'Income Distribution and the Process of Development'. European Economic Review, 44 (4-6): 706-12.

Galor, Oded and Weil, David.2000. From Malthusian Stagnation to modern Growth, American Economic Review, Vol. 89, No.2, p. 150-154.

Getachew S. 1991. A change in the role and status of pastoral women in two Gari villages, Southern Ethiopia. Ethiopia.

GIZ.H, 2013. Gender and value chain, Deutsche Gesell schaft for International Zusammenarbeit.

Gul Unal, F .2008. Small Is Beautiful: Evidence of an Inverse Relationship between Farm Size and Yield in Turkey. Working Paper No. 551, The Levy Economics Institute P.O. Box 5000 Annandale-on-Hudson, NY 125045000 .

Harkness, 2010. The Contribution of Women's Employment and Earnings to Household Income Inequality: A Cross-Country Analysis. Centre for Analysis of Social Policy and Department of Social and Policy Studies, University of Bath.

Hui-Shung Christie, 2010. Women in sweet potato marketing in Papua_ew Guinea.

ICA-ILO .2001. Gender Issues in Cooperatives: An ICAILO Perspective. From <http: //www.ica.coop/gender/ ica-ilo-manual/background.html\#roles> (RetrievedMarch 29, 2007)

Iheke, O.R. 2006. Gender and Resource Use Efficiency in Rice Production Systems in Abia State of Nigeria. An Unpublished M.Sc Thesis, Dept. of Agric Economics, Micheal Okpara University of Agriculture, Umudike.

In depth Analysis of the Ethiopian Demographic and Health Survey.2005. Gender inequality and women empowerment, Ethiopian Society of Population Studies. 
Institutions No. 2, National Bureau of Economic Research, NY.

Jamison, D. \& Lau, L. 1982. Farmer education and farmer efficiency: John Hopkins press for the World Bank.

Joshua Sikhu Okonya and Jürgen Kroschel. 2014. Gender differences in access and use of selected productive resources among sweet potato farmers in Uganda.

Jude Anayochukwu Mbanasor, 2012. Analysis of income inequality and poverty dynamics among rural farm households in Abia state, Nigeria.

Khamis A. Shauri.2013. An Assessment of Village Savings and Loans Associations on Household Income At Southern Unguja, A Dissertation Submitted in Partial Fulfillment of the Requirements for the Degree of Master of Science in Economics (Project Planning and Management) of Mzumbe University

Lemlem Aregu,Clare Bishop-Sambrook, Ranjitha Puskur and Ephrem Tesema,2010. Opportunities for promoting gender equality in rural Ethiopia through the commercialization of agriculture. IPMS (Improving Productivity and Market Success) of Ethiopian Farmers Project Working Paper 18. ILRI (International Livestock Research Institute), Nairobi, Kenya. 84 pp.

Lemma,.2008. Study on women"s property rights in Afar and Oromiya Regions, Ethiopia. USAID and CARE.

Li Gan.2013. Income Inequality and Consumptionin China. Texas A\&M University, College Station, Texas.USA Southwestern University of Finance and Economics, Chengdu, China.

Liaqat Ali.2013. Analysis Of The Determinants Of Income And Income Gap Between Urban And Rural Pakistan, interdisciplinary journal of contemporary research in business, VOL 5, NO 1

Liaqat.A, Muhammad.I and ZekeriyaNas . Analysis of the Determinants Of Income And Income Gap Between Urban And Rural Pakistan. Al-Khair University, Pakistan, VOL 5, NO 1

Litchfield, J. and McGregor, Th.1999. Poverty in Kagera, Tanzania: Characteristics, Causes and Constraints. PRUS Working Paper no. 42, August.

Lorenzo Giovanni Bellù, 2006. Inequality Analysis; the Gini Index, Food and Agriculture Organization of the United Nations, FAO.

Mankiw, N. Gregory., Romer, David and Weil, David N., ( 1992), 'Contribution to the Empirics of Economic', The Quarterly Journal of Economics, vol. 107, no. 2 pp. 407-437.

Mathias Marie Adrien Ndinga(2012). Gender income inequality and development in Africa: Analysis based on Kuznets' inverted U curve, Faculty of Economics, Marien Ngouabi University of Brazzaville, P. O. Box 69 Bayardelle, Congo Brazzaville:Journal of African Studies and Development Vol. 4(2), pp. 37-50,

Mathias Marie Adrien Ndinga, 2003. Gender income inequality and development in Africa: Analysis based on Kuznets, Faculty of Economics. Faculty of Economics, Marien Ngouabi University of Brazzaville.

Methodology Guide for Global Study( 2013). Innovation and Development through Transformation of Gender Norms in Agriculture and Natural Resource Management

Mincer, J. 1994. Schooling, Experience, and Earnings. Human Behavior and Social

Mincer, J. 1998. Schooling, Experience, and Earnings. Human Behavior and Social Institutions No. 2, National Bureau of Economic Research, NY.

Ministry of Agriculture and Rural Development/MoARD.2006. Guidelines for Gender Mainstreaming in Agriculture and Rural Development

Mitiku Haile et al. 2011. Research Report 2, Land registration in Tigray, Northern Ethiopia.?????

Morduch,J. and T.sicular. 2020. Rethinkin inequality Decomposition with Evidence from Rural China. The Economic Journal 112:93-106.

Nina de Roo .2011. Concept note on gender integration in CASCAPE

Nyanga, PH. and Umar, BB. 2012. A Polycentric approach to rural poverty reduction: Case of Zambian smallholder farmers Progress. A conference paper for IFPRI; Norwegian University of Life Sciences, Department of International Environment and Development Studies, P.O. Box 5003, NO-1432. Aas.

Odame HH, Hafkin. N, Wesseler G, Boto I .2002. Gender and Agriculture in the Information Society. International Service for National Agricultural Research Briefing Paper No.55. The Hague, The Netherlands: ISNAR.

Okoye, B.C., Onyenweaku, C. E., Ukoha, O.O., Asumugha, G.N and Aniedu, O.C .2008. Determinants of Labour Productivity on Small-holder Cocoyam Farms in Anambra State, Nigeria. Academic Journals Scientific Research and Essay. Vol 3(11): 559-561

Okoye.2014. Determinants of gender productivity among small- holdercocoyam farmers' in nsukka agricultural zone of enugu state, Nigeria: Dept. of Agricultural Extension, University of Nigeria, Nsukka.

Olagunju.F; Fakayode, Babatunde, .and Ogunwole-Olapade, 2007. Gender Analysis of agriculture Production in Osun State, Nigeria. Andrew Ridgewel Livelihoods \& Income Development in Ethiopia.

Oluwatayo, I. B. 2005. The Effect of Poverty on Children's Upbringing in Ibadan, Oyo State, Nigeria: A Case Study of Abadina Community. Multidisciplinary Journal of Empirical Research Vol. 2, No. 1, pp. $21-30$.

Oluwatayo.B, 2009. Poverty and Income Diversification among Households in Rural Nigeria. Gender Analysis of Livelihood Patterns.

Omwoha J.N, 2007, Gender Contribution and Constrains to Rural Agriculture and Household Food Security in 
Kenya: Case of Western Province.

Opio.F, 2003. Gender mainstreaming in agriculture with special reference to Uganda:Challenges and prospects. African Crop Science Conference Proceedings, Vol. 6. 699703.

Oyinbo Oyakhilomen, 2013. Gender influence on the income of maize farmers in Giwa local government area of Kaduna state.

Quisumbing, A.R. .1994. "Gender Differences in Agricultural Productivity: A Survey of Empirical Evidence". EPS Discussion Paper, No. 6, Education and Social Policy Development. The World Bank, Washington DC.

Ranjan S. Karippai and Hedija Mohammed, 2004. Introspection in to rural women empowerment in Ethiopia, paper presented in National Education Seminar in Bahir Dar University, Ethiopia.

Ranjitha Puskur. 2010. The role of gender in crop value chain in Ethiopia

Raphael O. Babatunde and Matin, 2006. Poverty and income inequality in rural Nigeria: The role of off-farm income diversification: Department of Agricultural Economics and Farm Management, University of Ilorin, Kwara State, Nigeria.

Reshid A, 2004. The Role of Women in Agro-Pastoral Household Food Security-The Case Of Erer Woreda, Shinile Zone, Somali National Regional States. Regional and Local Development Studies (RLDS).

S.Harkness, 2010. The Contribution of Women's Employment and Earnings to Household Income Inequality: A Cross-Country Analysis. Centre for Analysis of Social Policy and Department of Social and Policy Studies,University of Bath.

Senait, S, 2000. Gender issues in food security in Ethiopia: Reflections, no 7, Panos, Addis Ababa, Ethiopia.

Sherri Haas, 2005. Economic Development and the Gender Wage Gap.

Shorrocksaf. 1982.The impact of Income Componenet on the distribution of Family Income.Qartualiy Journal of Economics,98:311-26.

Spieldoch. A.2007. Row to Hoe. The Gender Impact of Trade Liberalization on ourFood System, Agricultural Markets and Women's Human Rights. Institute for Agriculture and Trade Policy (IAIP) International Gender abd Trade Network (IGTN): Frierich-Ebert-Stiftung Geneva, Switzerland.

$\mathrm{Su}, \mathrm{B} . \& H e s h m a t i, \mathrm{~A} .(2013)$. Analysis of the determinants of income andincome gap between urban and rural China. Discussion Paper No. 7162,IZA.

SWARDO. 2006. Sodo zuria woreda, Agriculture and Rural Development Office, Annual report.

Teshome A. 2005. Inequality and Agriculture in Ethiopia: A Case Study.

Udry, C., Hoddinott, J., Alderman, H. and Haddad, L. (1995) 'Gender Differentials on Farm Productivity: Implications for Household Efficiency and Agricultural Policy, 20,: 407-423.

WDR ,2006 .Background Paper on Asset Inequality and Agricultural Productivity. University of Sussex,UK.

Welch, Finis. 2000. 'Growth in Women's Relative Wages and in Inequality among Men: One Phenomenon or Two?' The American Economic Review, Vol. 90, No. 2, Papers and Proceedings of the One Hundred Twelfth Annual Meeting of the American Economic Association. (May, 2000), pp. 444-449.

World Bank.1997. Vietnam: Deepening reform for growth, Washington, D.C.

World Bank.2001. Engendering Development through Gender Equality in Rights, Resources and Voice. World Bank Policy Research Report 21776.Washington, D.C. and London: World Bank and Oxford University Press.

Yonas, 2011, Women and Land Rights in Rural Ethiopia: The Case of Wolaita. Faculty of Humanities, Social Sciences and Education University of Tromsø Norway. MSc. Thesis.

Z. Okatch , A.Siddique and Anu Rammohan,2003. Determinants of Income Inequality In Botswana: Business School University of Western Australia.

Zelda Okatch, Abu Siddique and Anu Rammohan, 2003. Determinants of income inequality in Botswana, Business School University of Western Australia.

Zeresina H, 2012. Gender, Agriculture and Food security,United Nation Develompment program. 